\title{
Corporate Governance and Leverage on Tax Aggressiveness: Empirical Study on Mining Companies in Indonesia
}

\author{
Laurensia Vanesali ${ }^{1}{ }^{*}$, Ari Budi Kristanto ${ }^{2}$ \\ 1,2 Fakultas Ekonomika dan Bisnis, Universitas Kristen Satya Wacana
}

\section{A R T I C L E I N F O}

Article history:

Received 01 December 2019

Received in revised form

31 December 2019

Accepted 15 January 2020

Available online 26

February 2020

Keywords:

Tax aggressiveness,

institutional ownership,

audit committee

independent commissioners,

leverage

\section{A B S T R A C. T}

This study aims to investigate the effect of corporate governance and leverage towards tax aggressiveness. The research data comprises 66 firm-year obtained from 11 mining companies during 2013-2018. They were sorted using a purposive sampling method. The hypotheses were tested using multiple regression analysis. The results indicate that institutional ownership and audit committee had a positive and significant effect on tax aggressiveness, the proportion of independent commissioners and audit quality had a negative and significant effect on tax avoidance, while leverage was not considered as a determinant of tax avoidance in Indonesian manufacturing firms.

\footnotetext{
* Corresponding author.

E-mail addresses: 232016192@student.uksw.edu (Laurensia Vanesali)
} 


\section{Introduction}

Tax aggressivenes refer to any activities in reducing taxes in an illegal, legal or both way (Yoehana, 2013). The motivation of tax aggressiveness is profit reducing effect from each dolar paid for tax (Rozak, Hardiyanto, \& Fadilah, 2017). Tax aggressiveness can be disadvantage to the government, since these activities will reduce the tax income (Octaviana, 2014).

Conflict of interest occurs between tax payers in managing company's tax and the tax authorities (Asri \& Suardana, 2016). This is due to tax is considered as an expense that results in reducing a company's profit, therefore the company try to find any way to reduce the tax (Asri \& Suardana, 2016). Tax regulations itself contain loopholes that can be used by companies to do the tax aggressiveness (Ngadiman \& Puspitasari, 2014).

Corporate Governance (CG) has a role in managing the impact of agency problems between parties in regard to the tax avoidance (Armstrong, Blouin, Jagolinzer, \& Larcker, 2015). Darmawan \& Sukartha (2014) states that the existence of CG can reduce the occurrence of agency problems where the goals achieved by managers are not in accordance with the expectation of shareholders, so the harmonization between shareholders and managers will affect tax decisions.

A company's policy in financing activities may also regulate the use of debt to finance company activities or commonly called leverage (Ngadiman \& Puspitasari, 2014). Leverage is a ratio to show the level of debt used by companies (Aprianto \& Dwimulyani, 2019). The amount of interest expense will be higher if the amount of debt in a company was high, this reduces the amount of corporate tax expense (Susilowati, Widyawati, \& Nuraini, 2018).

In Indonesia, the case of PT Adaro has suspected as a tax aggressive practices through transfer pricing transactions from 2009 to 2017, PT Adaro pays the tax at Rp 1.75 trillion lower than the original amount (Sugianto, 2019). According to Rahadian (2019), Indonesia relies on the coal mining sector because coal mining is considered as one of the sources of non-tax state revenue, two of the many coal mines in Indonesia are considered in the list of coal mines with the largest amount of production in the world. Therefore, Indonesia ranked as the fifth largest supplier in the world.

Fraudulent behavior in taxation is one of the reasons why government revenue from tax sources is still below the target. The following is the 2013-2018 budgeted tax revenue and its realization data (Kementrian keuangan, 2018; Kementrian Keuangan, 2016):

Table 1. State Budget Data 2013-2018 (in Trillion Rupiah)

\begin{tabular}{llll}
\hline Year & Target & Realization & Precentage \\
\hline 2013 & $1.529,7$ & 1.502 & $95,4 \%$ \\
2014 & $1.246,1$ & $1.143,3$ & $91,7 \%$ \\
2015 & $1.761,6$ & $1.491,5$ & $84,7 \%$ \\
2016 & 1.539 & 1.283 & $83,4 \%$ \\
2017 & 1.283 & 1.147 & $89,4 \%$ \\
2018 & 1.424 & $1.315,9$ & $92,4 \%$ \\
\hline
\end{tabular}

According to Table 1, there was a decrease in the percentage of tax revenue in 2013-2016, but again increased in 2017-2018 even though the revenue target had not been reached. The target nominal fluctuations in 2013, 2014, 2016, 2017 and 2018 are not greater than in 2015, which should have been increasing annually.

Sandy \& Lukviarman (2015) has examined the effect of good corporate governance variables on tax avoidance of the manufacturing companies listed on the Indonesia Stock Exchange in 2011 until 2013. This research will replicate previous research and provide additional leverage variabel, and a focus into the mining companies which listed on the Indonesia Stock Exchange in 2013 to 2018. Therefore, the research question in this research are: (1) Does institutional ownership have a positive effect on tax aggressiveness?; (2) Does the proportion of independent directors have a negative affect on tax aggressiveness?; (3) Does audit quality have a negative affect on tax aggressiveness?; (4) Does the audit committee have a negative effect on tax aggressiveness?; (5) Does leverage have a positive effect on tax aggressiveness?.

This research aims to determine the effect of corporate governance and leverage on tax aggressiveness activities in mining companies which listed on the Indonesia Stock Exchange in 2013 to 2018. The results are expected to contribute the literature about tax aggressiveness and can help the government in assessing the tax aggressiveness motives. 


\section{Methods}

Type of Source of Data

This research is a quantitative study using secondary data sources. The data source is obtained through the Indonesia Stock Exchange (IDX) website by taking information contained in financial statement documents (profit before tax, number of independent commissioners, KAP information, etc.). This study uses time series data and cross sections. This study processes data from the financial statements of several companies in the 2013-2018 period.

Population and Sample

Mining companies listed on the Indonesia Stock Exchange (BEI) in 2013-2018 are the population used in this study. Sampling in this study with a purposive sampling method. The criteria for mining companies, namely: (1) Mining companies that publish financial statements that end as of December 31, 2013 to 2018; (2) There were no losses to mining companies in 2013 to 2018, because losses could have a negative impact on ETR; (3) Companies whose financial statements have complete information about each variable examined.

Definition of Operation Variables

In this study, the dependent variable was tax aggressiveness and it can be calculated by Effective Tax Rate (ETR). The formula is as follows:

\section{ETR $=\frac{\text { Current Tax Expense }}{\text { Profit Before Tax }}$}

On the other hand, the independent variables included intitutional ownership, proportion of independent directors, audit quality, audit commitee and leverage. The proportion of independent directors is measured by a ratio of:

$$
\text { PKI }=\frac{\text { Total of Independent Commissioners }}{\text { Total of Commissioners }} \times 100 \%
$$

The measurement of audit quality can be seen from the level of the Public Accounting Firm (KAP) itself. Companies that entrust services from a large KAP (Big Four) will get a value of 1, but those who do not use a large KAP will get a value of 0 . Audit committee in a company consists of at least 3 (three) people (Otoritas Jasa Keuangan Republik Indonesia, 2015). Leverage is measured by a ratio of:

$$
\text { DER }=\frac{\text { Total Liabilities }}{\text { Total Assets }}
$$

\section{Data Analysis}

Multiple regression analysis became the data analysis technique in this study. Before the data is processed, the regression model must pass several classic assumption tests, including: Normality Test, Heteroscedasticity Test, Multicollinearity Test, and Autocorrelation Test. The multiple regression equation in this study:

$$
\mathrm{AP}=\alpha+\beta 110+\beta 2 \mathrm{IC}+\beta 3 \mathrm{AQ}+\beta 4 \mathrm{AC}+\beta 5 \mathrm{LEv}+\varepsilon
$$

Notes:

$\begin{array}{ll}\alpha & =\text { Regression equation constant } \\ \text { TA } & =\text { Tax aggressiveness } \\ \text { IO } & =\text { Institutional ownership } \\ \text { IC } & =\text { Proportion of independent commissioners } \\ \text { AQ } & =\text { Audit quality } \\ \text { AC } & =\text { Audit Committee } \\ \text { Lev } & =\text { Leverage } \\ \beta 1,2,3,4,5 & =\text { Regression Coefficient } \\ \varepsilon & =\text { Error term }\end{array}$




\section{Result And Discussion}

\section{Research Result}

Table 2. Sample Overview

\begin{tabular}{ll}
\hline Remarks & Total \\
\hline Mining companies listed on the Indonesia Stock Exchange in 2013-2018 & 47 \\
Mining companies that do not provide complete annual financial reports for 2013-2018 & $(6)$ \\
Mining companies that experienced a net loss or a fiscal loss in 2013-2018 & $(30)$ \\
Final total sample & 11 \\
Observation year & 6 \\
\hline Amount of observation data & 66
\end{tabular}

Mining companies listed on the Indonesia Stock Exchange (BEI) in 2013-2018 were the object of this research data. A total of 47 mining companies have been listed on the IDX, 41 of which were registered in the 2013-2018 period. Mining companies can be used as a sample of 11 companies, because in 2013-2018 there were 30 mining companies that experienced both net and fiscal losses that did not meet the requirements as a sample of this research data. The observation period of this study was 6 years, so the number of observational data in this study was 66.

Table 3. Descriptive Statistics

\begin{tabular}{llllll} 
Variables & Mean & Median & Minimum & Maximum & Stv.dev \\
\hline AP & 0,49 & 0,40 & 0,00 & 2,00 & 0,16 \\
KI & 56,62 & 58,37 & 21,35 & 90,74 & 10,25 \\
PKI & 0,39 & 0,40 & 0,33 & 0,50 & 3,18 \\
AUDIT & 0,64 & 1 & 0 & 1 & 0 \\
KomAudit & 3,18 & 3 & 2 & 4 & 0 \\
DER & 0,44 & 0,42 & 0,14 & 0,80 & 0,06 \\
\hline
\end{tabular}

Table 3 shows that the mean value of tax aggressiveness measured by the Effective Tax Rate (ETR) of $49 \%$ and corporate tax rate in Indonesia of $25 \%$, mining companies have a low tax aggressiveness . A minimum value of 0.00 can be interpreted as having a high aggressiveness, and a maximum value of 2.00 can be interpreted as having a low aggressiveness. The average value of institutional ownership in mining companies is $56.62 \%$ of the total outstanding shares, so that more than half of the outstanding shares are owned by institutions. Mining companies have at least $21.35 \%$ institutional ownership and have a maximum of $90.74 \%$ institutional ownership. The mean value of the proportion of independent directors is 0.39 , then $39 \%$ of all boards of commissioners in mining companies consist of independent commissioners. Mining companies have at least 33\% independent commissioners and have a maximum of $50 \%$ independent commissioners. The mean value of audit quality is $64 \%$, so that $64 \%$ of mining companies audit their financial statements in the big four. Mining companies that do not audit their financial statements in large KAP are four companies and those that audit their financial reports in large KAP are seven companies. The mean value of the audit committee is 3.18 , so the average number of audit committees in the mining company is 3.18 people. Mining companies have at least 2 audit committees and have a maximum of 4 audit committees. The mean value of leverage is 0.44 , so the average mining company pays its debt with $44 \%$ of the assets they own. Mining companies pay the least amount of debt with $14 \%$ of assets and up to $80 \%$ of assets.

Table 4. The Result of Classic Assumption Test

\begin{tabular}{lll}
\hline Test & Result & Conclusion \\
\hline Normality test & Significant $>0.05$ & Pass \\
Heteroscedasticity test & The point spreads above and below the number 0 on the & Pass \\
& Y axis. & \\
Multicollinearity test & Tolerance $>0,100$ & Pass \\
& VIF $<10,00$ & Pass \\
\hline
\end{tabular}


This research model has passed the classical assumption test, including: normality test, heteroscedasticity test, multicollinearity test, and autocorrelation test, so that the research model is feasible to continue the regression test.

Table 5. The Results of The Multiple Regression Analysis of Tax Aggressiveness

\begin{tabular}{lll}
\hline Variable & B & Sig. \\
\hline Institutional ownership & $-0,517$ & 0,000 \\
Proportion of independent commissioners & 0,248 & 0,027 \\
Audit quality & 0,342 & 0,006 \\
Audit Committee & $-0,296$ & 0,034 \\
Leverage & 0,149 & 0,201 \\
$R^{2}$ & 0,461 & \\
\hline
\end{tabular}

Tabel 5 shows the Institutional ownership has a negative and significant effect on the effective tax rate (ETR), so that high institutional ownership will result in high tax aggressiveness activities. The proportion of Independent Commissioners has a positive and significant effect on ETR, so that a high proportion of Independent Commissioners will result in a low tax aggressiveness activity. Audit quality has a positive and significant effect on ETR, so it can be concluded that high audit quality will result in low tax aggressiveness activities. The audit committee has a negative and significant impact on tax aggressiveness, so that a high audit committee will produce high tax aggressiveness activities. Leverage

has no effect on ETR, so low and high leverage does not affect tax aggressiveness activities. $R^{2}$ of this study was 0.461 or $46.1 \%$, so that the dependent variable was influenced together by the five independent variables amounting to $46.1 \%$.

\section{Discussion}

\section{Institutional Ownership on Tax Aggressiveness}

Institutional ownership has a positive and significant effect on tax aggressiveness, because it has a negative coefficient with a significant value not exceeding 0.05 . The first hypothesis states that high institutional ownership will result in high tax aggressiveness activities, so the hypothesis is accepted.

Institutional ownership is one of the factors driving management performance in the company, this will drive supervision on management performance to a maximum. Institutional parties can have power in overseeing management policies if the majority of shares are held by institutional parties. Management policies that are monitored by institutional parties tend to create policies that can reduce risks that are detrimental to shareholders. Corporate management tends to be forced to do tax aggressiveness if the company has a number of institutional ownership, so the dividends distributed are large. A high percentage of institutional ownership will provide strong control from external parties (institutional parties) over the company's management, so that it can pose a risk of tax aggressiveness activities (Feranika, 2014). Institutional ownership has a positive and significant influence on tax aggressiveness expressed by Feranika (2014) and Ngadiman \& Puspitasari (2014) who support this study. High institutional ownership tends to put pressure on company management which results in tax aggressiveness activities.

\section{Proportion of Independent Commissioners on Tax Aggressiveness}

The proportion of independent directors has a negative and significant effect on tax aggressiveness, because the coefficient value is positive and the significant value does not exceed 0.05 . The second hypothesis states that the high proportion of independent directors will result in low tax aggressiveness activities, so the hypothesis is accepted.

Good Corporate Governance (GCG) is created because the role of independent commissioners who take part in the company, the role of independent commissioners will not be far from the role of the board of commissioners. An independent commissioner will direct the company about good governance and will arrange so that the company becomes more effective and efficient in carrying out its operational activities. The Independent Commissioner also supervises management so that the company continues to adhere to the principles of good governance. Management is encouraged by independent commissioners to be careful in making decisions so as to minimize tax aggressiveness activities (Wijayanti \& Merkusiwati, 2017). The proportion of independent directors has a negative influence on tax aggressiveness stated by 
Eksandy (2017) and Sandy \& Lukviarman (2015) support this study. The high number of independent directors tends to reduce tax aggressiveness activities.

\section{Audit Quality on Tax Aggressiveness}

Audit quality has a negative and significant effect on tax aggressiveness, because it has a positive coefficient with a significant value not exceeding 0.05 . The third hypothesis states that high audit quality will result in low tax aggressiveness activity, so the hypothesis is accepted.

Audit quality is judged by the size of the Public Accounting Firm (PAF) used by the company. Investors will consider the quality of audits in making investment decisions. Companies that audit their financial statements in large PAF (the big four) tend to have high quality, because people consider large PAF must have high independence. Large PAF are more likely to maintain their independence reputation so as to override the activity of manipulating financial statements in accordance with the wishes of the company. Disclosure of incorrect financial statements not only affects the image of the company but also affects the image of the PAF that audits the financial statements. Companies that are audited by the big four PAF tend to have a low probability of tax aggressiveness (Eksandy, 2017). Audit quality has a negative effect on tax aggressiveness stated by Dewi \& Jati (2014), Khairunisa et al. (2017), and Sandy \& Lukviarman (2015) who support this study. Tax aggressiveness tends to be low if the company has audit quality.

\section{Audit Committee on Tax Aggressiveness}

The audit committee has a positive and significant influence on tax aggressiveness, because the coefficient is negative with a significant value not exceeding 0.05 . The fourth hypothesis states that a high audit committee will result in low tax aggressiveness, so the hypothesis is rejected.

The audit committee has a positive and significant impact on tax aggressiveness, the high audit committee which will produce high tax aggressiveness activities. The audit committee has a positive influence on tax aggressiveness stated by Prayogo (2015) and Sarra et al. (2014) which is in line with the regression results. IDX regulations state that the minimum number of committees is three, companies that have more than three audit committees can increase activities to reduce profits for tax purposes (Sarra et al., 2014). The process of making financial statements will be overseen by the audit committee (Pradana, 2016). Financial Services Authority Regulation No.55 / POJK.04 / 2015 requires companies to have an audit committee, so the formation of an audit committee tends to be done solely to meet these requirements (Sari, 2017).

\section{Leverage on Tax Aggressiveness}

Regression results show that leverage has no effect on tax aggressiveness, because the significant value does not exceed 0.05 . The fifth hypothesis states that high or low leverage ratios do not affect tax aggressiveness activities, so the hypothesis is rejected.

High or low leverage has no influence on tax aggressiveness activities in mining companies. Debts to mining companies tend to be obtained from capital loans from shareholders and trade payables arising from purchases for company operations, so there will be no interest expense that can reduce company profits. The actual impact of leverage is the interest expense from loans used to increase the company's operational activities, so that not all interest expenses can be categorized as deductible expenses as stipulated in Law No. 36 of 2008 article 6 paragraph 1a. Determination of debt as capital and taxable income (PKP) taxpayers can be recalculated by the Director General of Tax (DJP) regulated in Law No. $36 / 2008$ article 18. Leverage has no influence on tax aggressiveness stated by Vidiyanti (2017) and Alviyani (2014) which is in line with this study. Leverage is the company's operational financing with debts from third parties, high interest costs have an impact on small company profits so that companies tend not to finance as much debt as possible (Ngadiman \& Puspitasari, 2014).

\section{Conclussion}

Based on the results, it can be concluded that:

1. Institutional ownership has a significant positive effect on tax aggressiveness.

2. Proportion of independent directors has a significant negative effect on tax aggressiveness.

3. Audit quality has a significant negative effect on tax aggressiveness.

4. Audit committee has a significant positive effect on tax aggressiveness.

5. Leverage has no effect on tax aggressiveness. 
This research is consistent with the research of Ngadiman \& Puspitasari (2014), Feranika (2014), Eksandy (2017), Sandy \& Lukviarman (2015), Khairunisa et al. (2017), Dewi \& Jati (2014), Prayogo (2015), Sarra et al. (2014) which states that corporate governance has a significant influence on tax aggressiveness. Then, Vidiyanti (2017) and Alviyani (2014) stated that leverage has no influence on tax aggressiveness.

The results of this study can have implications for the tax authorities to consider institutional ownership factors, the proportion of independent commissioners, audit committees and audit quality as an indication of the risk of tax aggressiveness. From this research can provide information about the number of institutional ownership, independent commissioners and audit committees can affect the level of risk of tax aggressiveness activities. In addition, audit quality is quite important to reduce tax aggressiveness activities.

Some limitations of this study include:

1. The object of this study is mining companies listed on the Stock Exchange in 2013-2018 with a total of 46 companies, with companies that fit the criteria of 11 results from purposive. Many mining companies suffer losses, so the results of this study have a risk of bias if this conclusion is used to generalize to mining companies.

2.This study measures CG based on institutional ownership, the proportion of independent commissioners, audit quality, and audit committee as determinants of tax aggressiveness.

Suggestions for future research:

1. Future researchers who replicate this research model by replacing measures of tax aggressiveness other than ETR, for example book-tax difference in order to obtain more samples;

2. Further research uses other variables in the concept of CG such as CEO duality, top share, and others.

\section{Reference}

Aprianto, M., \& Dwimulyani, S. (2019). Pengaruh Sales Growth Dan Leverage Terhadap Tax Avoidance Dengan Kepemilikan Institusional Sebagai Variabel Moderasi. Prosiding Seminar Nasional Pakar Ke $2,1-10$.

Armstrong, C. S., Blouin, J. L., Jagolinzer, A. D., \& Larcker, D. F. (2015). Corporate Governance, Incentives, and Tax Avoidance. Journal of Accounting and Economics, 60(1), 1-17. https://doi.org/10.1016/i.jacceco.2015.02.003.

Asri, I. A. T. Y., \& Suardana, K. A. (2016). Pengaruh Proporsi Komisaris Independen, Komite Audit, Preferensi Risiko Eksekutif dan Ukuran Perusahaan Pada Penghindaran Pajak. E-Jurnal Akuntansi Universitas Udayana, 16, 72-100.

Darmawan, I. G. H., \& Sukartha, I. M. (2014). Pengaruh Penerapan Corporate Governance, Leverage, Return on Assets, dan Ukuran Perusahaan pada Penghindaran Pajak. E-Jurnal Akuntansi Universitas Udayana, 1, 143-161.

Dewi, N. N. K., \& Jati, I. K. (2014). Pengaruh Karakter Eksekutif, Karakteristik Perusahaan, dan Dimensi Tata Kelola Perusahaan yang Baik pada Tax Avoidance di Bursa Efek Indonesia. E-Jurnal Akuntansi Udayana, 6(2), 249-260.

Diantari, P., \& Ulupui, I. (2016). Pengaruh Komite Audit, Proporsi Komisaris Independen, Dan Proporsi Kepemilikan Institusional Terhadap Tax Avoidance. E-Jurnal Akuntansi, 16(1), 702-732.

Eksandy, A. (2017). Pengaruh Komisaris Independen, Komite Audit, dan Kualitas Audit Terhadap Penghindaran Pajak (Tax Avoidance). Competitive Jurnal Akuntansi Dan Keuangan, 1(1), 1. https://doi.org/10.31000/competitive.v1i1.96

Feranika, A. (2014). Pengaruh Kepemilikan Institusional, Dewan Komisaris Independen, Kualitas Audit, Komite Audit, Karakter Eksekutif, dan Leverage Terhadap Tax Avoidance. STIE Ahmad Dahlan Jakarta, 4(1), 31-39. 
Kementrian keuangan. (2018). Informasi APBN 2018. 1-266.

Kementrian Keuangan. (2016). Informasi APBN 2016 (Information on the 2016 State Budget).

Khairunisa, K., Hapsari, D. W., Aminah, W., \& Telkom, U. (2017). Kualitas Audit, Corporate Social Responsibility, dan Ukuran Perusahaan Terhadap Tax Avoidance. 9(1), 39-46.

Kurniawati, M., \& Toly, A. A. (2014). Analisis Keadilan Pajak, Biaya Kepatuhan, dan Tarif Pajak terhadap Persepsi Wajib Pajak mengenai Penggelapan Pajak di Surabaya Barat. Tax \& Accounting Review, $4(2), 1-12$.

Merslythalia, D. R., \& Lasmana, M. S. (2016). Pengaruh Kompetensi Eksekutif, Ukuran Perusahaan, Komisaris Independen, dan Kepemilikan Institusional Terhadap Tax Avoidance. Jurnal Ilmiah Akuntansi Dan Bisnis, 11(2), 117-124.

Ngadiman, \& Puspitasari, C. (2014). Pengaruh Leverage, Kepemilikan Institusional, dan Ukuran Perusahaan Terhadap Penghindaran Pajak (Tax Avoidance) pada Perusahaan Sektor Manufaktur yang Terdaftar di Bursa Efek Indonesia 2010-2012. XVIII(03), 408-421.

Nurfadilah, Mulyati, H., Purnamasari, M., \& Niar, H. (2015). Pengaruh Leverage, Ukuran Perusahaan, dan Kualitas Audit Terhadap Penghindaran Pajak ( Studi Empiris pada Perusahaan Manufaktur yang terdaftar di Bursa Efek Indonesia Tahun 2011-2015 ). Seminar Nasional Dan The 3rd Call for Syariah Paper, (2010), 441-449.

Octaviana, N. E. (2014). Pengaruh Agresivitas Pajak Terhadap Corporate Social Responsibility: Untuk Menguji Teori Legistimasi. Journal of Chemical Information and Modeling, 53(9), 1689-1699. https://doi.org/10.1017/CB09781107415324.004

Oktamawati, M. (2019). Pengaruh Karakter Eksekutif, Komite Audit, Ukuran Perusahaan, Leverage, Pertumbuhan Penjualan, dan Profitabilitas Terhadap Tax Avoidance. Jurnal Akuntansi Bisnis, 15(1), 23-40. https://doi.org/10.24167/jab.v15i1.1349

Otoritas Jasa Keuangan Republik Indonesia. (2015). Peraturan Otoritas Jasa Keuangan No 13 /POJK.03/2017 Tentang Penggunaan Jasa Akuntan Publik dan Kantor Akuntan Publik dalam Kegiatan Jasa Keuangan.

Pradana, A. B. (2016). Pengaruh Karakteristik Dewan Komisaris Terhadap Agresivitas Pajak.

Prayogo, K. H. (2015). Faktor-faktor yang Berpengaruh Terhadap Penghindaran Pajak Perusahaan. 4, 112.

Rahadian, A. (2019). Ini 10 Negara dengan Produksi Batu Bara Terbesar di Dunia. Cnbcindonesia.Com. Retrieved from https://www.cnbcindonesia.com/news/20190429200726-16-69567/ini-10negara-dengan-produksi-batu-bara-terbesar-di-dunia

Rozak, T. S., Hardiyanto, A. T., \& Fadilah, H. (2017). Pengaruh Profitabilitas, Likuiditas, dan Leverage Terhadap Tax Avoidance.

Sandy, S., \& Lukviarman, N. (2015). Pengaruh Corporate Governance Terhadap Tax Avoidance: Studi Empiris pada Perusahaan Manufaktur.

Sari, I. H. N. (2017). Pengaruh Komite Audit, Dewa Komisaris, Ukuran Perusahaan dan Leverage Terhadap Manajemen Laba. Jurnal Akuntansi Fakultas Ekonomi Universitas Muhammadiyah Surakarta, 1, 121.

Sarra, H. D., Fakultas, D., Universitas, B., Tangerang, M., Kunci, K., Pajak, P., \& Rate, E. T. (2014). Pengaruh Konservatisme Akuntansi, Komite Audit dan Dewan Komisaris Independen Terhadap Penghindaran Pajak (Studi Empiris Pada Industri Kimia dan Logam di Bursa Efek Indonesia Periode 2010-2014). 
Sugianto, D. (2019). Mengenal soal Penghindaran Pajak yang Dituduhkan ke Adaro. Detik.Com. Retrieved from https://finance.detik.com/berita-ekonomi-bisnis/d-4612708/mengenal-soal-penghindaranpajak-yang-dituduhkan-ke-adaro? ga=2.192569706.176534186.1570381435$\underline{1524251187.1569934884 .}$.

Susilowati, Y., Widyawati, R., \& Nuraini. (2018). Pengaruh Ukuran Perusahaan, Leverage, Profitabilitas, Capital Intensity Ratio, dan Komisaris Independen Terhadap Effective Tax Rate (Studi Empiris pada Perusahaan Manufaktur yang Terdaftar di Bursa Efek Indonesia pada Tahun 2014-2016). (2014), 978-979.

Vidiyanti, E. (2017). Pengaruh Komite Audit, Kualitas Audit, Kepemilikan Institusional, Return on Assets, dan Leverage Terhadap Tax Avoidance. 4, 9-15.

Yoehana, M. (2013). Analisis Pengaruh Corporate Social Responsibility Terhadap Agresivitas Pajak. Skripsi Universitas Diponegoro, 1-62 